\title{
MEMOTIVASI SISWA-SISWI SMK MUHAMMADIYAH PARUNG- BOGOR MENJADI SISWA-SISWI UNGGULAN SEBAGAI PERSIAPAN MEMASUKI JENJANG PERGURUAN TINGGI DAN DUNIA KERJA
}

\author{
${ }^{1}$ Dede Andi, ${ }^{2}$ Hira Maulida, ${ }^{3}$ Irfan Rizka Akbar, ${ }^{4}$ Muhamad Abid, \\ ${ }^{5}$ Melda Wiguna \\ Dosen Fakultas Ekonomi, Universitas Pamulang \\ Email : $\underline{1}$ dede.andi87@gmail.com
}

\begin{abstract}
ABSTRAK
Tujuan dari Kegiatan Pengabdian Kepada Masyarakat adalah untuk melaksanakan salah satu Tri Darma Perguruan Tinggi. Selain itu diharapkan dengan pengabdian kepada masyarakat tersebut keberadaan perguruan tinggi dapat memberikan kontribusi besar kepada pengembangan dan penerapan keilmuan kepada masyarakat.

Metode yang digunakan pada Pengabdian Kepada Masyarakat ini berupa penyuluhan dan pembinaan yaitu suatu tindakan, proses, hasil, atau pernyataan yang lebih baik. Dalam hal ini menunjukkan adanya kemajuan, peningkatan pertumbuhan, evolusi atas berbagai kemungkinan, berkembang atau peningkatan atas sesuatu.

Hasil pengabdian masyarakat yang diperoleh adalah bertambahnya keilmuan bagi para para siswa dan siswi yang dilakukan pada kelas 3 Jurusan Otomatisasi Tata Dan Kelola Perkantoran 1 dan 2 SMK Muhammadiyah J1. H. Mawi No. 292 Desa Bojong Indah, Kecamatan Parung, Kabupaten Bogor 16330 yang berjumlah 52 peserta, agar mereka memiliki pandangan yang baik bagaimana motivasi belajar, cara mempersiapkan diri memasuki perguruan tinggi dan dunia kerja.
\end{abstract}

\section{Kata Kunci : Motivasi Siswa, Persiapan Memasuki Perguruan Tinggi Dan Dunia Kerja}

\section{PENDAHULUAN}

Belajar telah menjadi salah satu hal yang sangat penting bagi remaja. Ini masalahnya, anak muda saat ini lebih cenderung belajar malas dan memilih kegiatan lain yang menurut mereka lebih menarik. Orang-orang muda dengan ketidakmampuan belajar tentu memiliki alasan yang berbeda, ada yang bosan dengan pelajaran karena nilainya terus turun, ada yang tidak antusias belajar, dan ada yang kesulitan berkonsentrasi ketika disuruh belajar.

Remaja memang rentan terhadap hal-hal baru seperti lingkungan dan hubungan baru. Ini juga salah satu faktor mengapa banyak remaja belajar malas. Cara meningkatkan minat dan motivasi siswa untuk belajar tidaklah mudah. 
Namun, jika diterapkan dengan sukses, itu berdampak besar pada kinerja dan kualitas siswa.

Dengan adanya materi tentang bagaiman cara memotivasi siswa-siswi agar menjadi unggul untuk persiapan memasuki perguruan tinggi dan dunia kerja para siswa diharapkan menjadi lebih bersemangat dalam belajar, terbuka, berani dan mampu mengatur arah hidup mereka secara mandiri dan bermanfaat untuk diri sendiri dan juga orang lain.

\section{METODE PELAKSANAAN}

Metode pelaksanaan kegiatan merupakan cara pelaksanaan yang menjelaskan secara singkat tata cara pelaksanaan program, adapun metode tersebut disajikan dalam bagan dibawah ini :

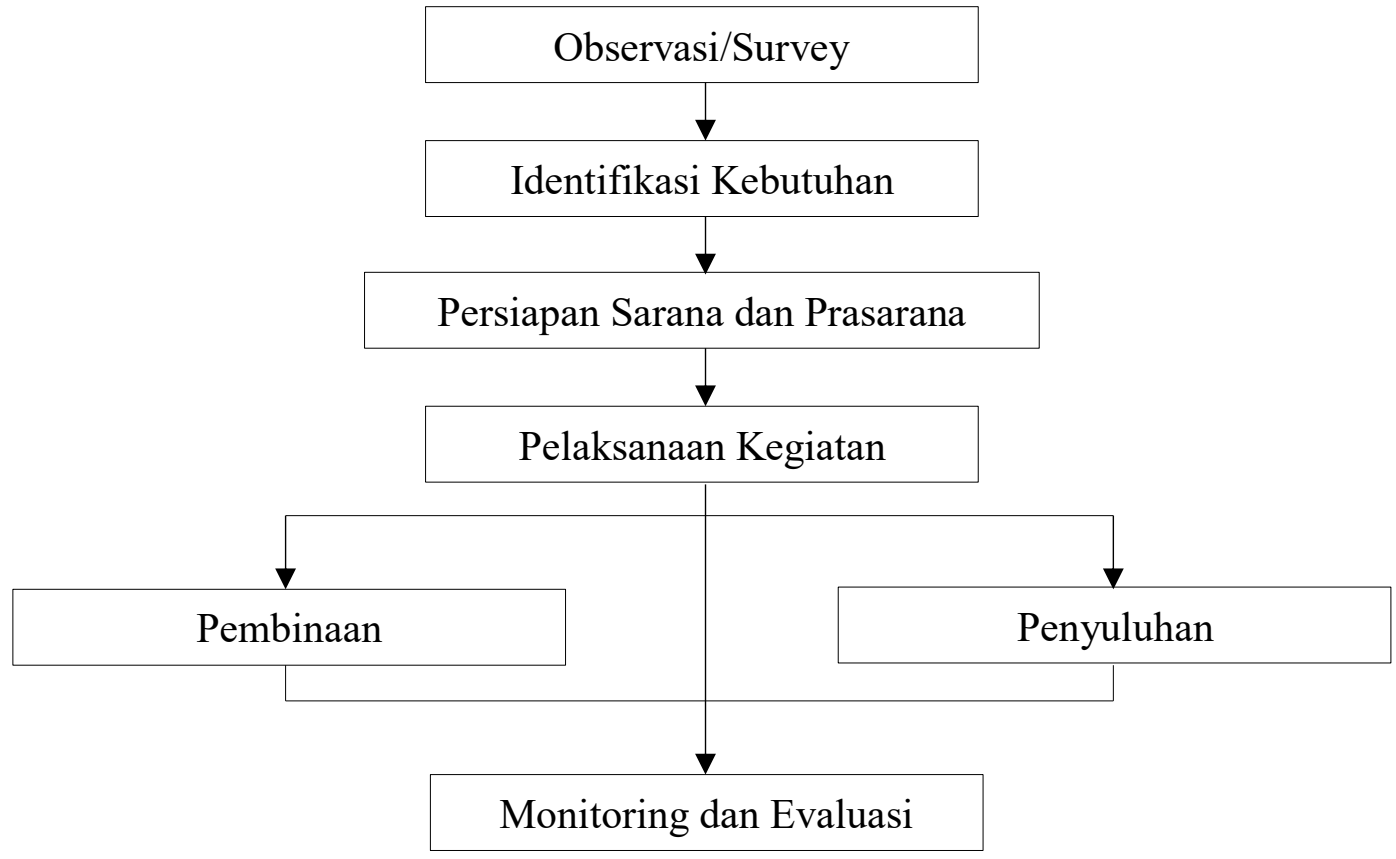

\section{Gambar 1. Metode Pelaksanaan Kegiatan Pengabdian Kepada Masyarakat}

Secara lengkap metode pelaksanaan kegiatan akan disajikan secara lengkap melalui penjelasan dibawah ini,

a. Survei Tempat Pelaksanaan Kegiatan

Kegiatan ini dimaksudkan untuk menggali informasi tentang kondisi geografis dan kondisi masyarakat didaerah tempat kegiatan. Informasi tersebut berupa lokasi, permasalahan yang dihadapi dalam pada lokasi tersebut

b. Persiapan Sarana dan Prasarana

Kegiatan ini dimaksudkan untuk merencanakan kebutuhan baik sarana dan prasarana yang akan digunakan dalam pelaksanaan kegiatan dengan tetap memperhatikan kebutuhan masyarakat secara umum dan khusus demi 
tercapainya target pengabdian kepada masyarakat. Sarana dan prasarana yang dimaksud berupa projektor, spanduk daln lain-lain.

c. Pelaksanaan Kegiatan,

Setelah melakukan survey dan persiapan sarana dan prasarana maka pelaksanaan kegiatan dilaksanakan oleh pengusul besrta anggota dan beberapa mahasiswa. Kegiatanyang dilakukan adalah berupa pembinaan dalam bentuk pertemuan secara langsung antara peserta didik kelas 3 SMK Muhammadiyah Parung yang menitikberatkan pada motivasi belajar siswa.

d. Monitoring dan Evaluasi,

Kegiatan ini dimaksudkan untuk meninjau perkembangan aktualisasi masyarakat terhadap kegiatan yang telah dilakukan sebelumnya dengan harapan dapat dilaksanakan sesuai dengan teori yang telahdi peroleh melalui kegiatan yang telah dilaksanakan. Evaluasi juga bertujuan untuk memahami pola pemahaman masyrakat terhadap informasi baru yang diperoleh dari pelaksana kegiatan. Hasil ini diharapkan mampu menjadi dasar pengembangan motivasi belajar siswa di sekitar.

\section{HASIL DAN PEMBAHASAN}

\section{A. Hasil Penyuluhan dan Pembinaan}

Kegiatan penyuluan dan pembinaan ke SMK Muhammadiyah ParungBogor tentang memotivasi siswa-siswi SMK Muhammadiyah Parung-Bogor menjadi siswa-siswi unggulan sebagai persiapan memasuki jenjang perguruan tinggi dan dunia kerja. Penyuluan dan pembinaan ini dilakukan pada kelas Kelas 3

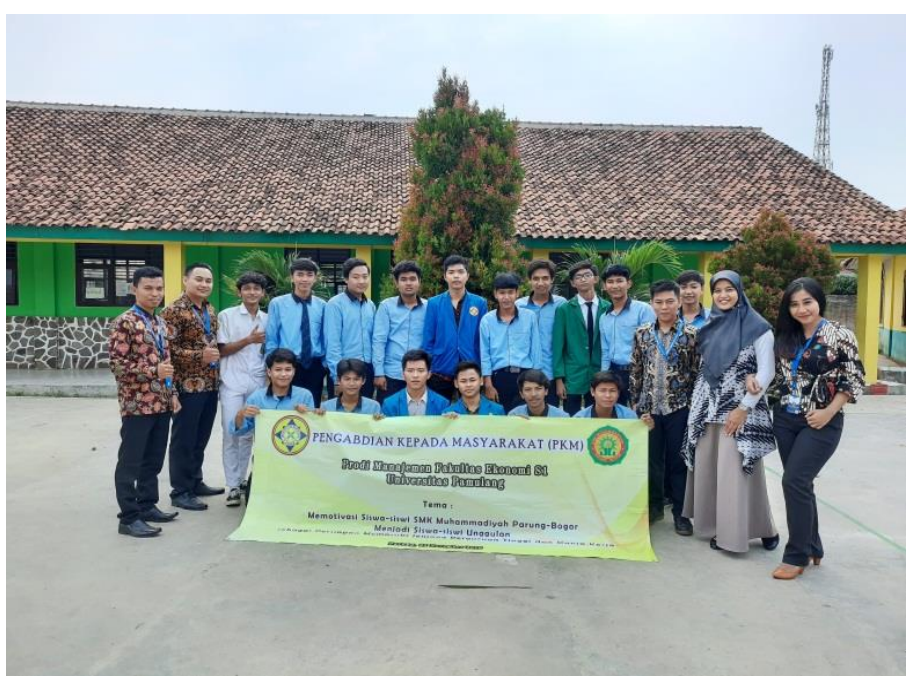
Jurusan Otomatisasi Tata Dan Kelola Perkantoran 1 dan 2 SMK Muhammadiyah Jl. H. Mawi No. 292 Desa Bojong Indah, Kecamatan Parung, Kabupaten Bogor 16330 yang berjumlah 52 peserta.

Kegiatan penyuluan dan pembinaa ini dimulai dengan menyanyikan lagu kebangsaan Indonesia Raya, Ice Breaking tujuannya untuk membuat suasana lebih akrab. Setelah itu, pemateri menayangkan slide power point yang berkaitan dengan materi memotivasi siswa. Respon dari siswa dan siswi Kelas 3 Jurusan Otomatisasi Tata Dan Kelola Perkantoran 1 dan 2 sangat baik. Terlihat ketika pemateri menanyakan motivasi belajar ke salah satu siswa respon siswa cepat menangkap pelajaran dari materi tersebut. 
Dalam kegiatan tersebut ada beberapa perubahan yang dilihat dari siswasiswi yang mengikuti kegiatan penyuluan dan pembinaan motivasi belajar, karena ada beberapa juga siswa yang sangat bersemangat dan termotivasi untuk lebih giat belajar. Mereka menyadari selama ini mereka sudah menyia-nyiakan waktu dalam belajar, dan mereka juga bertekad untuk lebih semangat dalam belajar agar dapat membanggakan kedua orangtuanya serta mencapai cita-cita yang mereka inginkan yaitu menjadi orang sukses di masa depan. Alhamdulillah kegiatan penyuluhan dan pembinaan motivasi belajar berjalan cukup baik, karena semua siswa aktif dan merespon dengan baik dalam kegiatan ini. Berdasarkan wawancara, tanya jawab dan pengamatan langsung selama kegiatan berlangsung, kegiatan pengabdian pada masyarakat ini memberikan hasil sebagai berikut :

1) Meningkatnya pengetahuan dan pemahaman siswa-siswi SMK Muhammadiyah Parung tentang tata cara belajar belajar agar menjadi siswa unggul, persiapan-persiapan memasuki perguruan tinggi dan persiapan memasuki dunia kerja

2) Meningkatnya semangat dan motivasi siswa-siswi untuk lebih giat lagi dalam belajar, serta antusias mereka dalam persiapan memasuki perguruan tinggi dan dunia kerja.

\section{B. Faktor pendukung dan faktor penghambat}

Beberapa faktor yang mendukung terlaksananya kegiatan pengabdian pada masyarakat ini adalah besarnya minat dan antusiasme peserta selama kegiatan, sehingga kegiatan berlangsung dengan lancar dan efektif. Sedangkan faktor penghambatnya adalah keterbatasan waktu penyuluhan dan pembinaan.

\section{KESIMPULAN DAN SARAN \\ Kesimpulan}

Pelaksanaan kegiatan Pengabdian Kepada Masyarakat oleh Lembaga Penelitian dan Pengabdian Masyarakat (LPPM) Universitas Pamulang yang dilakukan oleh dosen-dosen program studi Manajemen telah berjalan dengan lancar dan mendapat sambutan hangat dari tempat pelaksanaan kegiatan ini yaitu dilakukan pada kelas Kelas 3 Jurusan Otomatisasi Tata Dan Kelola Perkantoran 1 dan 2 SMK Muhammadiyah Jl. H. Mawi No. 292 Desa Bojong Indah, Kecamatan Parung, Kabupaten Bogor 16330 yang berjumlah 52 peserta.

Harapan kami dengan pengabdian ini dapat membuka wawasan dari siswa siswi kelas 3 Jurusan Otomatisasi Tata Dan Kelola Perkantoran 1 dan 2 SMK Muhammadiyah akan menghadapi dunia perguruan tinggi dan dunia kerja. Materi yang kami berikan yaitu penyuluhan dan pembinaan sehingga dapat membantu dan meningkatkan motivasi belajar, tingkat keilmuan dan keperibadian yang baik yang akan sangat bermanfaat dalam kehidupan mereka pada masa yang akan datang.

\section{Saran}


Mengingat besarnya manfaat kegiatan pengabdian pada masyarakat ini, maka selanjutnya perlu:

1) Mengadakan penyuluhan dan pembinaan serupa pada siswa sekolah lain di Kecamatan yang lain, dengan materi yang sama.

2) Adanya kesinambungan program pasca kegiatan pengabdian ini sehingga para siswa dan siswi benar-benar dapat termotivasi untuk masa depan baik persiapan memasuki perguruan tinggi dan persiapan memasuki dunia kerja.

\section{DAFTAR PUSTAKA}

Amirullah dan Budiono, Haris.,2003. Pengantar Manajemen. Jakarta: Cetakan Kedua. Yogyakarta: Graha Ilmu.

Agus Rahmat, W., 2000. "Landasan Etnis Kehidupan Politik” dalam Wajah Baru Etika dan Agama, Kanisius: Yogyakarta

Dimyati dan Mujiono. 2002. Belajar dan Pembelajaran. Rineka Cipta. Jakarta.

Hakim, Thursan. 2002. Mengatasi Rasa Tidak Percaya Diri. Jakarta: Puspa Swara.

Moekijat. 2002. Dasar-dasar Motivasi. Bandung: CV. Pionir Jaya.

Mustari, Mohamad. (2011). Nilai Karakter Refleksi Untuk Pendidikan Karakter. Jakarta: Laksbang Pressindo

Silaban, Saban Sopian. 2019. Siswa Diatas Garis.Gramedia Pustaka Utama, Indonesia.

Sondang P. Siagian, 2004. Teori Motivasi dan Aplikasinya. Jakarta: PT. Rineka Cipta.

Sinamo, Jansen. (2011). 8 Etos Kerja Profesional. Jakarta: Institut Dharma Mahardika

Sukardewi, Nyoman dkk. 2013. Kontribusi Adversity Quotient (AQ), Etos Kerja,Dan Budaya Organisasi Terhadap Kinerja Guru SMA Negeri Di Kota Amlapura. Volume 4 Tahun 2013. Singaraja Indonesia: Program Studi Administrasi Pendidikan, Program Pascasarjana Universitas Pendidikan Ganesha.

Tasmara, T. 2002. Etos Kerja Pribadi Muslim. Yogyakarta: Dana Bhakti Prima Yasa. 